\title{
Article \\ The Remediation Characteristics of Heavy Metals (Copper and Lead) on Applying Recycled Food Waste Ash and Electrokinetic Remediation Techniques
}

\author{
Sounghyun Lee ${ }^{1}$, Jung-Mann Yun ${ }^{2}$, Jong-Young Lee ${ }^{3}$, Gigwon Hong ${ }^{4}{ }^{(}$, Ji-Sun Kim ${ }^{1} \oplus$, Dongchan Kim ${ }^{5, *(1)}$ \\ and Jung-Geun Han ${ }^{3,6, *}$ \\ 1 Department of Civil Engineering, Chung-Ang University, Seoul 06974, Korea; flight1017@gmail.com (S.L.); \\ gellsomina@daum.net (J.-S.K.) \\ 2 Department of Smart Civil Engineering, ShinAnsan University, Ansan 15435, Korea; jmyun@sau.ac.kr \\ 3 School of Civil and Environmental Engineering, Urban Design and Study, Chung-Ang University, \\ Seoul 06974, Korea; geoljy@cau.ac.kr \\ 4 Department of Civil and Disaster Prevention Engineering, Halla University, Wonju-si 26404, Korea; \\ g.hong@halla.ac.kr \\ 5 Department of Geotechnical Engineering Research, Korea Institute of Civil Engineering and Building \\ Technology, Ilsan 10223, Korea \\ 6 Department of Intelligent Energy and Industry, Chung-Ang University, Seoul 06974, Korea \\ * Correspondence: dc_kim@kict.re.kr (D.K.); jghan@cau.ac.kr (J.-G.H.)
}

check for updates

Citation: Lee, S.; Yun, J.-M.; Lee, J.-Y.; Hong, G.; Kim, J.-S.; Kim, D.; Han, J.-G. The Remediation Characteristics of Heavy Metals (Copper and Lead) on Applying Recycled Food Waste Ash and Electrokinetic Remediation Techniques. Appl. Sci. 2021, 11, 7437. https://doi.org/10.3390/app11167437

Academic Editors: Seong-Jik Park, Chang-Gu Lee, Eun Hea Jho and Sanghyun Jeong

Received: 19 July 2021

Accepted: 10 August 2021

Published: 13 August 2021

Publisher's Note: MDPI stays neutral with regard to jurisdictional claims in published maps and institutional affiliations.

Copyright: (c) 2021 by the authors. Licensee MDPI, Basel, Switzerland. This article is an open access article distributed under the terms and conditions of the Creative Commons Attribution (CC BY) license (https:// creativecommons.org/licenses/by/ $4.0 /)$

Abstract: Most food waste is incinerated and reclaimed in Korea. Due to the development of industry, soil and groundwater pollution are serious. The purpose of this study was to study recycled materials and eco-friendly remediation methods to prevent secondary pollution after remediation. In this study, recycled food waste ash was filled in a permeable reactive barrier (PRB) and used as a heavy metal adsorption material. In situ remediation electrokinetic techniques (EK) and acetic acid were used. Electrokinetic remediation is a technology that can remove various polluted soils and pollutants, and is an economical and highly useful remediation technique. Thereafter, the current density increased constantly over time, and it was confirmed that it increased after electrode exchange and then decreased. Based on this result, the acetic acid was constantly injected and it was reconfirmed through the water content after the end of the experiment. In the case of both heavy metals, the removal efficiency was good after 10 days of operation and 8 days after electrode exchange, but, in the case of lead, it was confirmed that experiments are needed by increasing the operation date before electrode exchange. It was confirmed that the copper removal rate was about $74 \%$ to $87 \%$, and the lead removal rate was about $11 \%$ to $43 \%$. After the end of the experiment, a low pH was confirmed at $x / L=0.9$, and it was also confirmed that there was no precipitation of heavy metals and there was a smooth movement by the enhancer and electrolysis after electrode exchange.

Keywords: electrokonetic (EK); electrode exchange; remediation; PRB; heavy metals

\section{Introduction}

Currently, the quality of life for mankind has improved, but indiscriminate development and industrial development are threatening mankind and the ecosystem. Because of food waste, which is waste and household waste arising from the development of industry, there is concern about the importance of the soil environment in terms of soil and groundwater pollution [1]. Due to the aging of industry and industrial facilities, many pollution sources, as well as pollutants, have been exposed to the soil environment and have been contaminated for a long time [2-5]. Soil pollution has the characteristic that the remediation process is complex and costly. In addition, heavy-metal-contaminated soil can be directly affected by inhalation or contact with human skin, and can affect human health through indirect exposure channels, such as groundwater $[3,6,7]$. Food waste disposal 
using incineration is increasing steadily every year due to a prohibition on landfilling food waste. Most food waste is incinerated and reclaimed in Korea, and it is necessary to recognize that it is a resource through the recycling of food waste ash.

Recently, with the expansion of industrial complexes, the remediation of contaminated ground, such as those near factories, power plants, and clay shooting ranges, has emerged as an important issue [8]. A variety of technologies to remove and restore pollutants from soil have been developed and put into practical use. Among them, soil washing, soil vapor extraction, pumping water treatment, bioventing, and EK are mainly used as on-site restoration technologies in contaminated areas [9-13]. Since it is difficult to apply ex-situ remediation to complex facilities, various methods are being researched and developed as the number of cases of in-situ remediation of soil increases. Among the remediation techniques, in situ techniques are preferred in terms of cost reduction and for safety due to contaminants; the EK remediation technique is used as an in situ technique suitable for finegrained soil. Electrophoresis and electroosmosis are the main phenomena of heavy metal removal [3,14-16]; however, the EK remediation technique is characterized by reduced hydroxide precipitation and movement of heavy metals at the cathode $[9,15,17-21]$.

The EK remediation technique is being used to remove various pollutants such as heavy metals and organic matter. Improved EK techniques are being studied, and the performance of EK has been improved through research on various coating and electrode materials [22-25]. In addition, improved EK studies, such as multiple electrode arrangement [26,27], control of electrolyte $\mathrm{pH}[28,29]$, inorganic/organic acid [30-32] and chelants [32-34], have been conducted. The remediation effect has been improved by applying PRB [23,35,36], soil washing [37,38], bioremediation [39,40], and phytoremediation [41-43] together with EK.

The advantages of the electrokinetic remediation technique can be summarized as follows [44]: first, the electrokinetic remediation technique does not require complex equipment. Second, during electrokinetic remediation, workers or the general public are not exposed to pollutants. Third, electrokinetic remediation techniques can be used for soil, sludge, sediment, and groundwater. Fourth, it can be applied to metals, organic compounds, radionuclides, or complex pollutants. Fifth, it can be used in both in situ and ex situ remediation systems, and can be used in combination with other remediation technologies, such as bioremediation. Finally, compared to other thermal remediation techniques, low amounts of electrical energy are required and the overall cost is low. Costs range from $\$ 20$ to $\$ 225$ per cubic yard, depending on the site conditions.

In this study, to compensate for the disadvantages of the EK remediation method, recycled food waste ash was filled in PRB and used as an adsorbent. To prevent precipitation by hydroxide ions, the adsorbent was installed at $75 \%$ of the anode near the precipitation boundary, and heavy metals at the cathode were moved to the PRB through electrode exchange. To improve the movement of heavy metals, biodegradable acid was injected consistently using a Mariotte bottle. The contaminated ground typically is with contaminated with heavy metal copper and lead, and the remediation characteristics of copper and lead are identified to help the application of the remediation technique using recycled food waste ash.

\section{Materials and Methods}

2.1. Materials

\subsubsection{Soil Sample}

Kaolinite, which is an inactive clay and is stable against changes in water content, was used to simulate ground contaminated with heavy metal. It also has an affinity for heavy metals and homogeneity for indoor experiments [45]. Southeastern Clay Company's clay was used (kaolinite) and had almost no impurities. In the EK remediation experiment, the effect was confirmed in silty clay, which has a smaller plasticity than highly plastic clay, including expanded clay mineral [46]. In addition, kaolinite has a low cation exchange 
capacity (CEC) and a fast ion exchange reaction rate, so it is easy to check EK remediation characteristics for concentrations of heavy metal contamination.

\subsubsection{Food Waste Ash}

Figure 1 shows the particle size distribution of food waste ash. The diameter of ash had the largest particle size distribution at about $130 \mathrm{um}$. Food waste ash had an irregular particle surface and a porous structure, and the characteristics were confirmed by measuring the specific surface area. BET (Brunauer Emmett Teller) measurements were used by degassing nitrogen after lowering the pressure to $1 \mathrm{~Pa}(7.5 \mathrm{um} \mathrm{Hg})$ at $350{ }^{\circ} \mathrm{C}$ and the $\mathrm{BJH}$ (Barrett-Joyner-Halenda) model was used to measure the pore distribution. The device used for the experiment was a Micromeritics ASAP20 10, and the measurements were performed according to KS L ISO 18757. The specific surface area of the carbonized food waste material was $14.16\left(\mathrm{~m}^{2} / \mathrm{g}\right)$, the total pore volume was $0.0469\left(\mathrm{~cm}^{2} / \mathrm{g}\right)$, and the average pore diameter was $132.4(\AA)$. To solve the problem of hydroxide precipitation during EK remediation, PRB was used to prevent the adsorption and precipitation of heavy metals. A no. 100 sieve was used for the homogeneity of the material, and it is an eco-friendly material with an adsorption effect on heavy metals and organic matter. Food waste ash is a porous material and was used for heavy metal remediation through adsorption and precipitation of heavy metals.

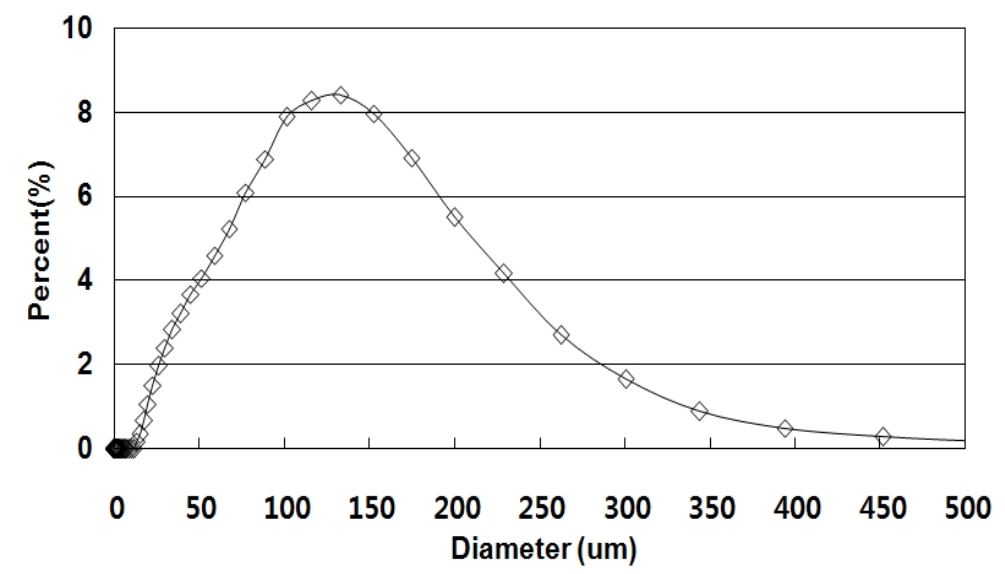

Figure 1. Particle size distribution.

\subsubsection{Improver}

Acetic acid was selected to improve the movement of heavy metals, copper and lead, which are contaminants in the ground. Surfactants and cleaning agents used in EK remediation techniques remain in the ground and cause secondary pollution. Acetic acid is a stable material that biodegrades over time and has excellent economic efficiency. In this study, $0.05 \mathrm{M}$ of acetic acid was injected into a Mariotte bottle.

\subsection{Experiments}

\subsubsection{Experimental Tools}

The experiment machine used in the experiment consisted of three devices, a DC power supply (DRP-901 DS, Digital Electronics), a Mariotte bottle, and a test cell, as shown in Figure 2. The test cell and Mariotte bottle were manufactured out of transparent acrylic.

The DC power supply converts alternating current into direct current, supplying voltage under constant fixed conditions, and the test cell consisted of a bubble tube and cylinder that could be used to free the outflow from electric osmosis during experiments and measure the flow rate. The Mariotte bottle was also used to inject the improver at the anode and maintain a constant level inside the cell with electrodes using carbon. 


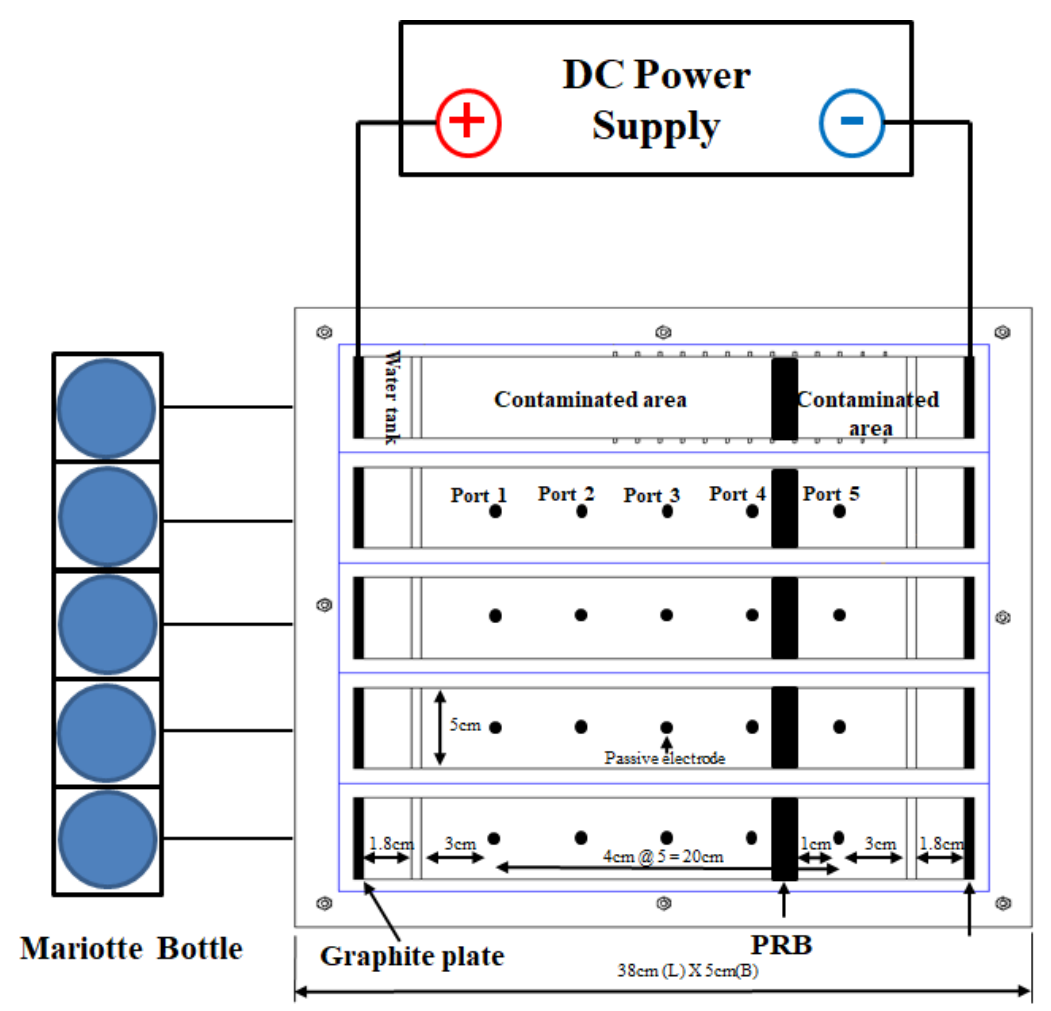

Figure 2. Schematic diagram and dimensions of the EK test device.

\subsubsection{PRB}

Since the 1990s, many in situ treatment methods for pollutant remediation have been studied, and research using PRB is still being actively pursued and developed. The PRB method was first reported by Mcmurthy and Elton [47], and a permeable barrier filled with a reactant is installed in the path that groundwater containing pollutants flows through. It is a method to remove pollutants by inducing a chemical reaction between reactants and pollutants when polluted groundwater passes through a wall. Figure 3 shows the mechanism by which the permeable reaction wall is removed according to the flow of groundwater. PRB is made of a porous plate in the same shape $(5 \mathrm{~cm} \times 4.3 \mathrm{~cm})$ as the contaminated sample and was installed. The pore water in the sample passed through the PRB, but the sample did not pass, so food waste ash was added in the PRB and used as an adsorbent.

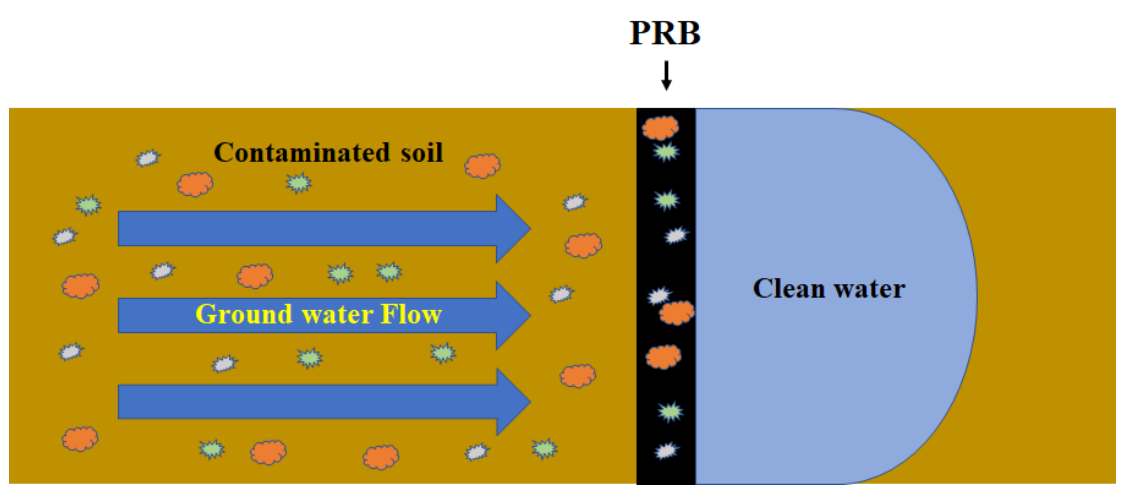

Figure 3. Permeable reactive barrier (PRB).

\subsubsection{Test Method}

A remediation experiment was conducted to analyze the characteristics of removal through an EK remediation experiment on the contaminated ground, using copper and lead, respectively. Copper (500 ppm) and lead (1000 ppm) were used for the contamination 
concentration according to Korean standards, and acetic acid (0.05 M) was used as an improving agent. For the heavy metal remediation experiment, an initial 10-day remediation period was set. After 10 days, the electrodes were changed and additional remediation experiments were performed at 6,8 , and 10 days. The electrode gradient was $1 \mathrm{~V} / \mathrm{cm}$, the location of the PRB was $x / L=0.75$, which is the point where the acid and base wires meet, and the thickness of the PRB was $1 \mathrm{~cm}$ [48]. During the experiment, the current density, $\mathrm{pH}$ changes in both water tanks, and the overflow were measured. After the end of the experiment, the water content, residual concentration of contaminants in the soil, and $\mathrm{pH}$ were determined according to KSTM (Korean standard testing method).

In this study, a cell test was conducted to analyze the removal characteristics of each contaminant from ground contaminated with copper and lead, respectively, using EK remediation techniques. In order to solve the precipitation problem caused by existing EK remediation techniques, PRB and acetic acid were used and food waste ash and electrode exchange were applied as the filling material of the PRB to induce adsorption of the pollutants. Based on this, the removal characteristics of ground contaminated with copper and lead, which are heavy metal pollutants, were analyzed. Table 1 below shows the EK test conditions.

Table 1. Test conditions.

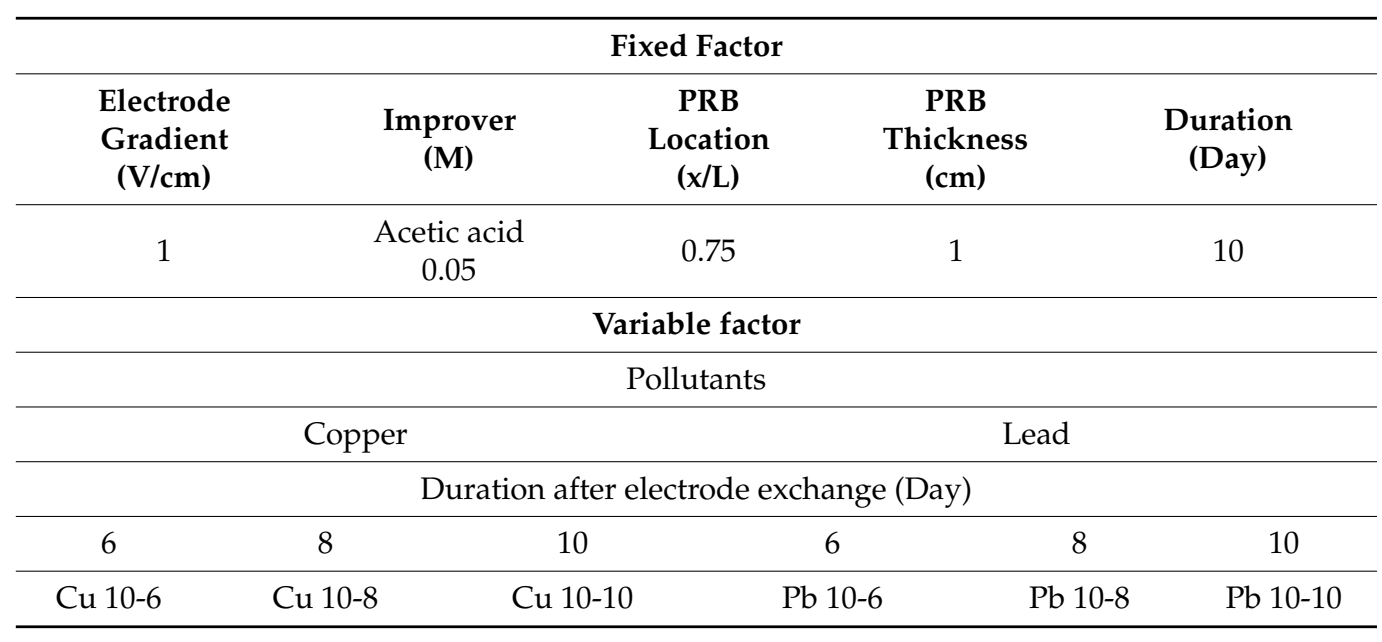

\section{Results}

\section{1. $p H$ Change}

Figure 4 shows the $\mathrm{pH}$ change in the anode water tank during the EK remediation experiment for copper and lead. After the start of EK remediation, the electrolysis phenomenon resulted in $\mathrm{pH}$ changes at the anode and cathode. Two hours after remediation, the cathode showed a low $\mathrm{pH}$ at the hydrogen ion $\left(\mathrm{H}^{+}\right)$and a high $\mathrm{pH}$ at the cathode $\left(\mathrm{OH}^{-}\right)$. After about $36 \mathrm{~h}$, the anode tank tends to show a low $\mathrm{pH}$ between 2 and 3 and the cathode tank shows a high $\mathrm{pH}$ between 12 and 13. Due to the changed electrode after the electrode exchange, the $\mathrm{pH}$ of the tank changes and the low $\mathrm{pH}$ of the cathode (initial anode) increases and the high $\mathrm{pH}$ of the anode (initial cathode) decreases. It was confirmed that the $\mathrm{pH}$ of both copper and lead decreased within $24 \mathrm{~h}$ after electrode exchange, and that the $\mathrm{pH}$ increased after 2 days in the changed anode. It was confirmed that the effect of hydrogen at the anode, according to EK remediation, was faster. 


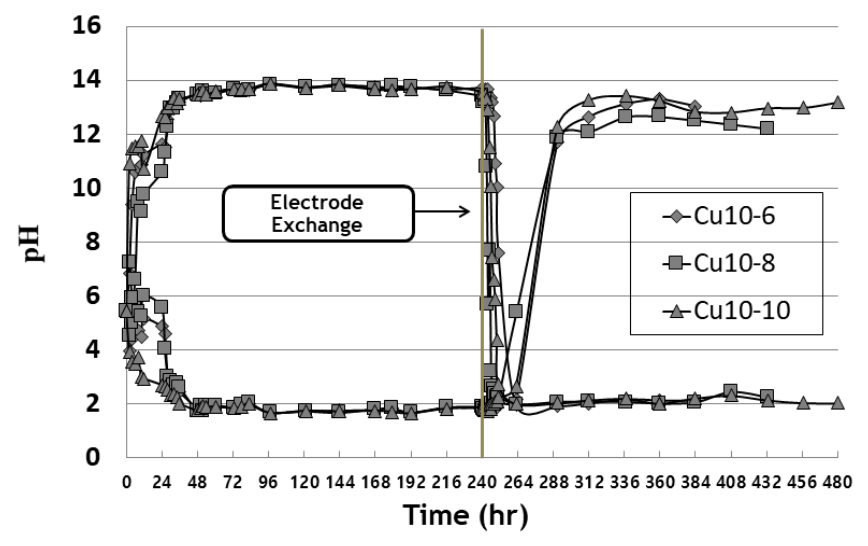

(a)

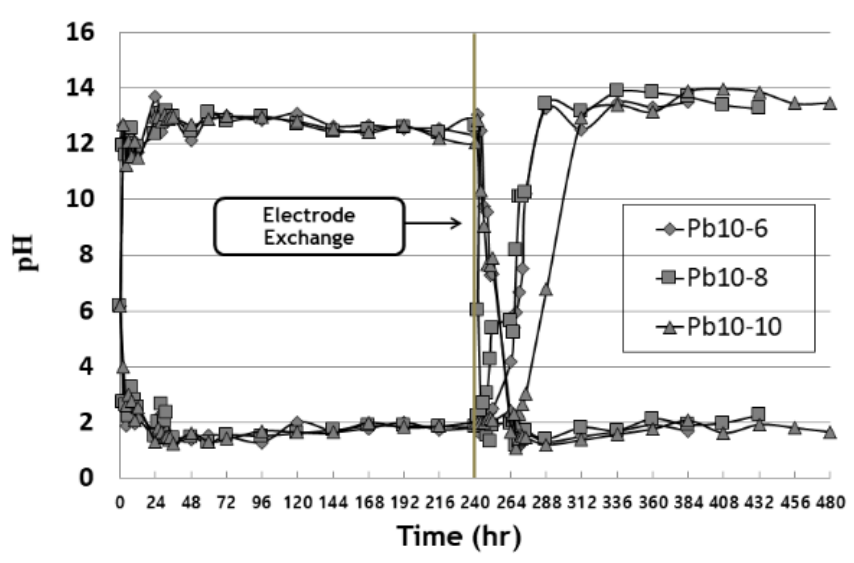

(b)

Figure 4. $\mathrm{pH}$ change of water tank during EK experiments: (a) copper; (b) lead.

\subsection{Current Density}

Figure 5 shows the change in current over time and the change in current density in EK remediation experiments, which vary the timing of the electrode exchange and the operation date after the exchange. The current density was calculated by dividing the total current passing through a cross section of the soil into the area of the test cell. The current density was expressed by dividing the measured current value by the soil sample $(5 \mathrm{~cm} \times 4.3 \mathrm{~cm})$. The current density decreased after its peak between 30 and $50 \mathrm{~h}$, showing very low values after running for about $100 \mathrm{~h}$; similar results were obtained in other similar studies. Furthermore, the current density after the electrode exchange decreased after the conductivity decreased again in the anode. After electrode exchange, the current density increased and then decreased. A precipitate was formed by hydroxide ions at the point where the cathode was before the electrode exchange. However, the $\mathrm{pH}$ was lowered due to the electrode exchange and the influence of the improver and EK, so that the heavy metals were ionized and the reduced conductivity increased.

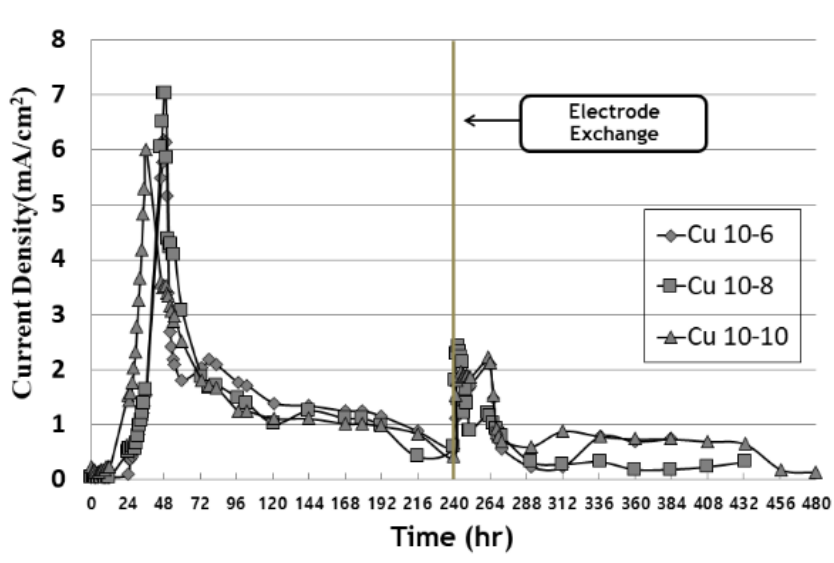

(a)

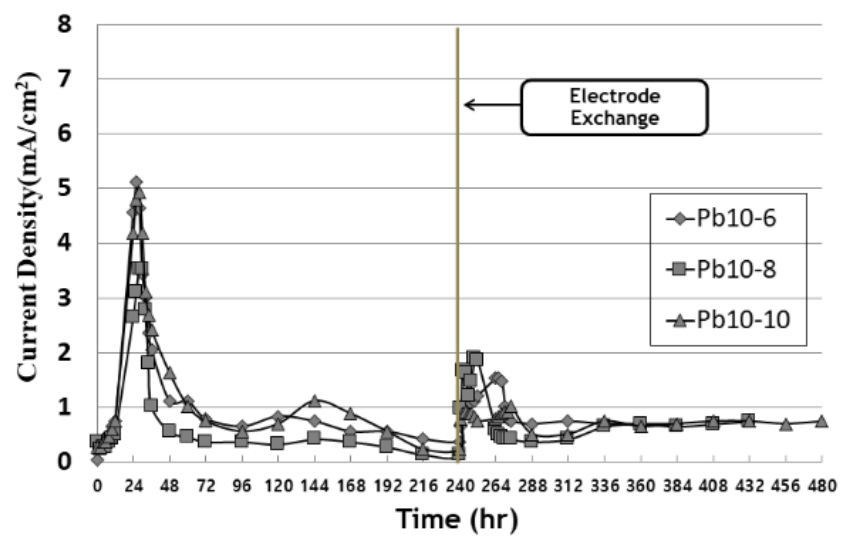

(b)

Figure 5. Current density during EK experiment: (a) copper; (b) lead.

\subsection{Outflow}

Figure 6 shows the cumulative outflow according to time. The amount of outflow tended to increase as the operation period grew longer, and the outflow volume increased after the electrode exchange. For this reason, the improver was injected at the beginning of the experiment and had a high water content, and the inlet part was converted into the 
outlet part through electrode exchange at the anode part. Therefore, it was determined that the electro-osmosis direction was reversed and the amount of effluent increased.

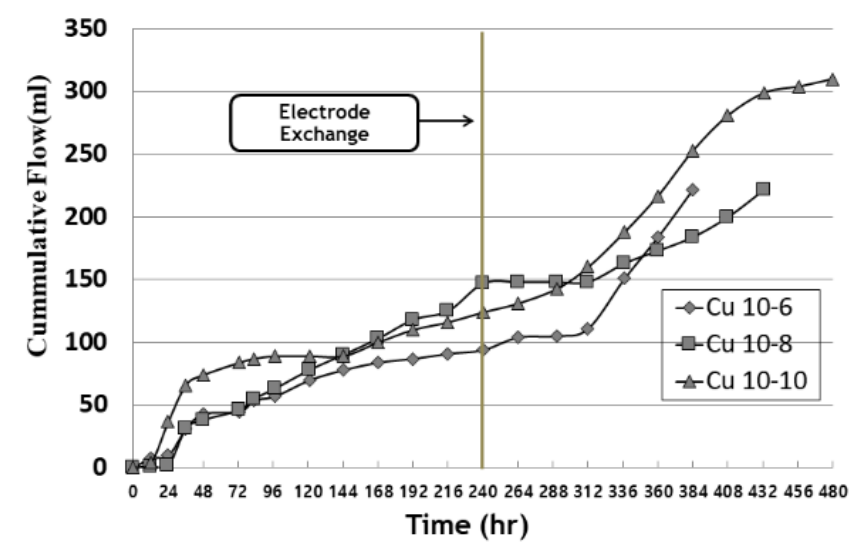

(a)

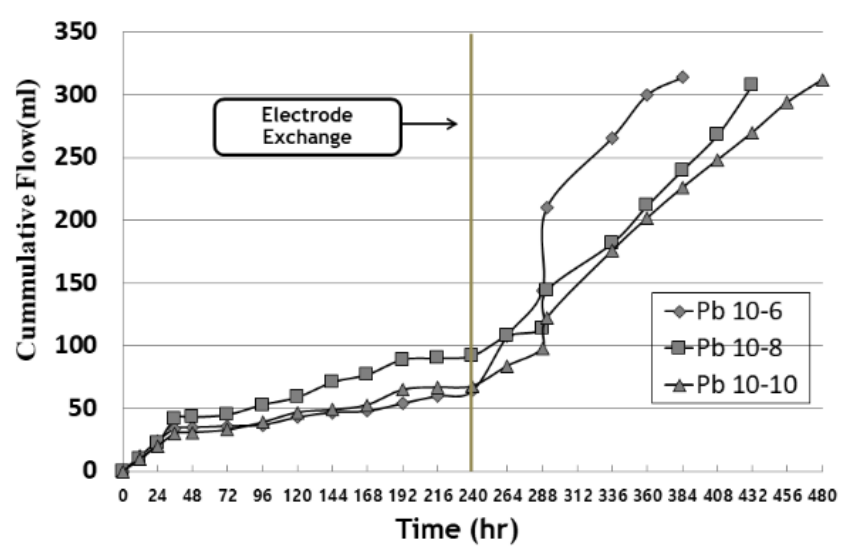

(b)

Figure 6. Cumulative outflow during EK experiment: (a) copper; (b) lead.

\subsection{Water Content}

Figure 7 shows the water content in the sample after the experiment was completed. After the experiment was completed, the water content of each sample was measured for each of five ports. The water content due to electrode exchange did not differ significantly at the initial overall water content of $60 \%$, and most of the initial anodes showed a water content slightly higher than the initial water content at $x / L=0.9$. In addition, most of the initial anodes showed a tendency to be lower than the initial water content at $x / L=0.1$. It is confirmed that the effect of electroosmosis is greater than the injection rate of the enhancer through the marriott bottle. This is the initial cathode through electrode exchange, and it is determined that the water content was slightly higher than the initial water content and was maintained because the improving agent was injected as the point at which the effluent exits become the anodes. Furthermore, the water content as a whole seemed to be maintained, similar to the initial water content, and it was determined that the sample did not settle during the EK remediation experiment and the movement of the improver was smooth.

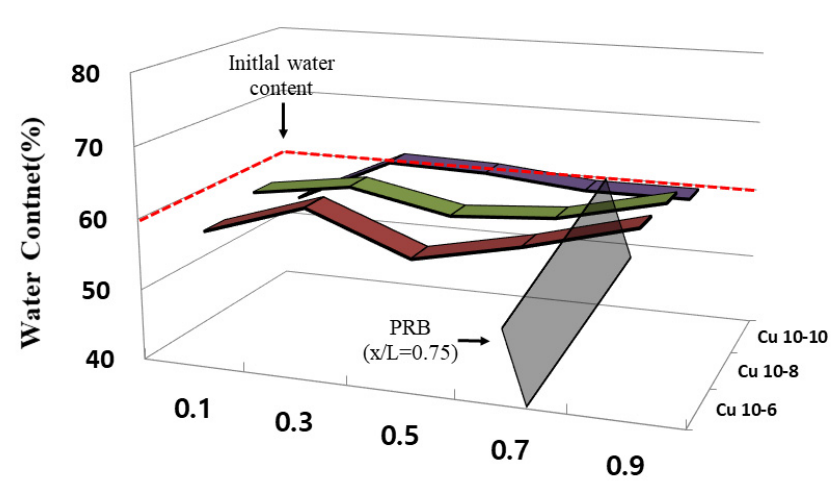

Normalized distance from initial Anode(x/L)

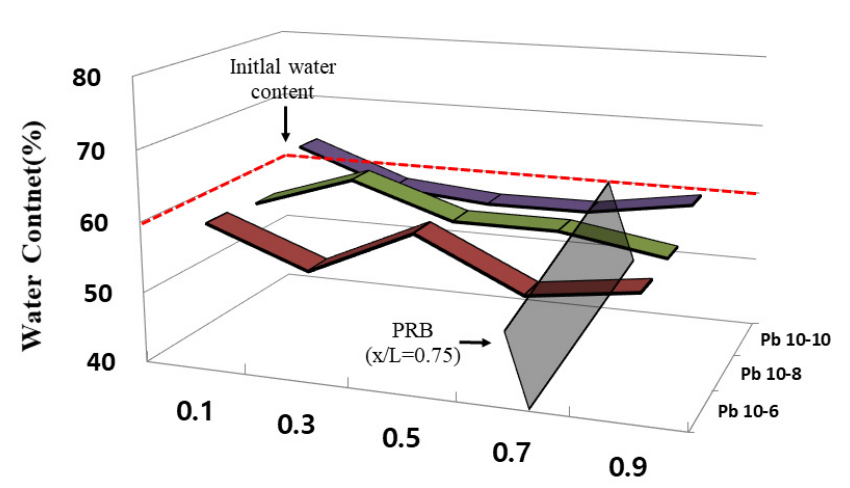

Normalized distance from initial $\operatorname{Anode}(\mathbf{x} / \mathrm{L})$

(a)

Figure 7. Water content after the end of the EK experiment: (a) copper; (b) lead.

\section{5. $\mathrm{pH}$ and Residue of Heavy Metals in Samples after the End of the EK Experiment}

Figure 8 shows the residual copper/lead in the sample and the $\mathrm{pH}$ measurement results following the end of the experiment at the time of electrode exchange. The $\mathrm{pH}$ 
distribution in the sample was similar to the typical $\mathrm{pH}$ distribution in the EK experiments, which resulted in a condition in which heavy metals remaining in the soil could move to the cathode part to precipitate due to the lower $\mathrm{pH}$ at the anode part.

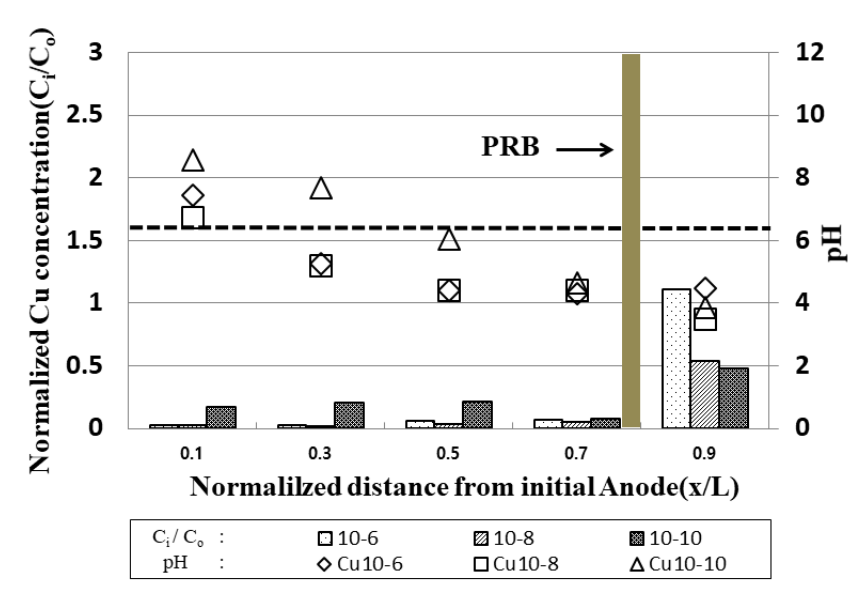

(a)

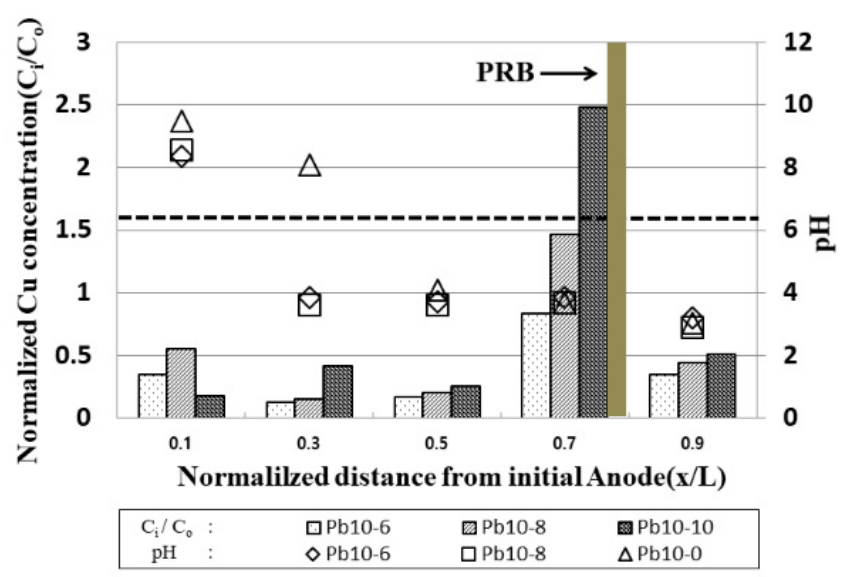

(b)

Figure 8. $\mathrm{pH}$ and residue of heavy metals in samples after the end of the EK experiment: (a) copper; (b) lead.

In the case of copper, the residual concentration at the $\mathrm{x} / \mathrm{L}=0.9$ point in the initial anode was significantly reduced, and, in the case of $\mathrm{Cu} 10-10$ operated for 10 days after electrode exchange, the residual concentration was significantly reduced to about $20 \%$ of the initial contamination concentration. However, it was confirmed that the residual concentration at the $\mathrm{x} / \mathrm{L}=0 \sim 0.7$ point in the initial anode increased as the operation day increased. CFW filled with PRB was precipitated in excess of the maximum adsorption amount; it is considered that the heavy metal remaining in the PRB moved to the inside of the sample due to the electrode exchange.

In the case of lead, it showed a similar tendency to copper, and a high amount of heavy metal was confirmed at the point $x / L=0.7$. This was confirmed to be higher than the initial pollution concentration due to the movement of heavy metals after 10 days of operation of copper and the electrode exchange. It was determined that the duration of EK should be longer than that for copper. In addition, the reason for the low $\mathrm{pH}$ in the sample near the anode in the initial stage was that the $\mathrm{pH}$ in the sample was lowered by the influence of hydrogen ions as the operation time before electrode exchange was prolonged. In the case of the initial cathode, it was confirmed that the $\mathrm{pH}$ increased and hydroxide ions after electrode exchange were easily lowered due to the injection of the improver. This is the effect of moving heavy metals from the anode to the cathode by electrophoresis and electro-osmosis during EK phenomena, and the effect of heavy metal remediation in the clay soil was confirmed [49-52].

In the case of lead, it was confirmed that the residual amount of heavy metals was higher than that of copper in the sample, and the adsorption of lead was higher than that of copper in kaolinite [53]. Due to the high adsorption, lead removal was also determined to be lower than that of copper. In addition, as a result of applying the EK remediation technique to soil contaminated with copper and lead, it can be confirmed that the remediation of lead is difficult $[34,35,54-58]$.

\subsection{Current and Outflow}

The outflow passing through the cathode water tank trough was measured every $24 \mathrm{~h}$ with a beaker. Figure 9 compares the current and the outflow rates for ground contaminated with copper and lead. The current was similarly observed for copper and lead at the maximum current value, from 30 to $50 \mathrm{~h}$, and showed a tendency to gradually decrease. After electrode exchange, it increased and then decreased again, and it was confirmed that the current value of copper was higher than that of lead. The outflow 
tended to increase and decrease as the current value increased, and, after the electrode exchange, the amount of outflow was confirmed to increase before the electrode exchange. It was confirmed that the amount of pore water at the $\mathrm{x} / \mathrm{L}=0 \sim 0.75$-point increases after electrode exchange as electro-osmosis occurred. In the case of copper, it was confirmed that the high current value moved more than lead in the contaminated soil.

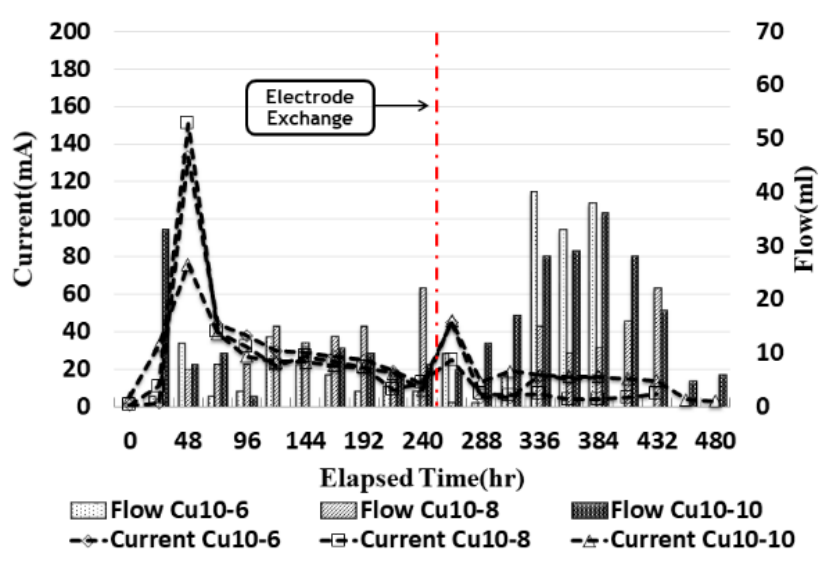

(a)

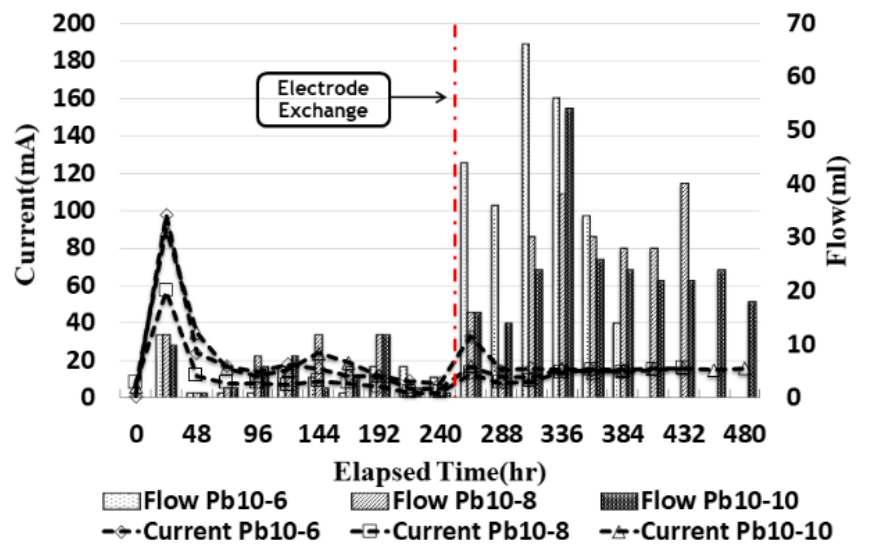

(b)

Figure 9. Current and outflow during the EK experiment: (a) copper; (b) lead.

\subsection{Mass Balance}

After the EK remediation experiment, the mass balance of heavy metal copper and lead was calculated, and the extraction of copper and lead contaminants adsorbed in the PRB was measured according to KSTM. The contaminated soil was sampled at five ports to measure the concentration of heavy metals, and the location of the ports could be determined as in Figure 2. Figure 10 and Table 2 show the mass balance after the EK remediation experiment. Most of the heavy metals in the sample were removed in the case of copper, but most of the lead remained in the soil. Most of the copper was adsorbed to the PRB, and it was confirmed that the removal rate was about $74 \%$ to $87 \%$. In the case of lead, the removal rate was $11 \%-43 \%$, and it was confirmed that the EK remediation efficiency was lower than that of copper. The removal rate for copper and lead was the best for 8 days of electrode exchange after 10 days of operation, but it was determined that additional research is needed on the remediation period for heavy metal lead.

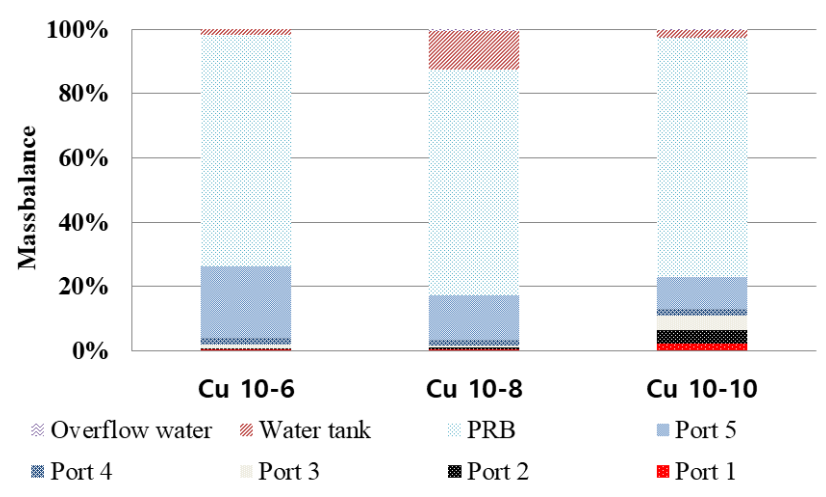

(a)

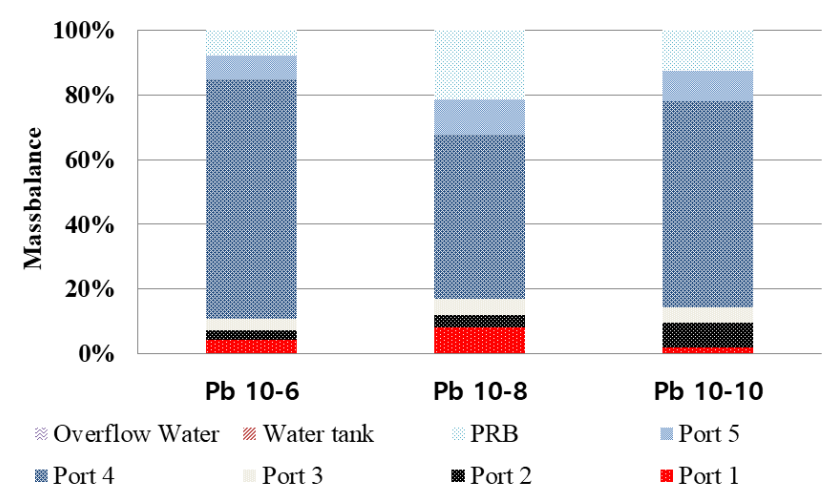

(b)

Figure 10. Mass balance: (a) copper; (b) lead. 
Table 2. Mass balance and removal rates.

\begin{tabular}{cccccccc}
\hline Test & $\begin{array}{c}\text { Initial Amount } \\
\text { of Pollutant } \\
(\mathbf{m g})\end{array}$ & $\begin{array}{c}\text { Residual in } \\
\text { the Soil } \\
(\mathbf{m g})\end{array}$ & $\begin{array}{c}\text { PRB } \\
(\mathbf{m g})\end{array}$ & $\begin{array}{c}\text { Outflow } \\
(\mathbf{m g})\end{array}$ & $\begin{array}{c}\text { Water Tanks } \\
(\mathbf{m g})\end{array}$ & $\begin{array}{c}\text { Mass Balance } \\
\mathbf{( \% )}\end{array}$ & $\begin{array}{c}\text { Removal Rate } \\
(\mathbf{\%})\end{array}$ \\
\hline $\mathrm{Cu} \mathrm{10-6}$ & 180 & 47.24 & 129.75 & 0.16 & 2.82 & 99.99 & 73.76 \\
$\mathrm{Cu} \mathrm{10-8}$ & 180 & 24.33 & 99.11 & 0.80 & 16.95 & 78.44 & 86.80 \\
$\mathrm{Cu} \mathrm{10-10}$ & 180 & 40.03 & 129.78 & 0.69 & 3.87 & 96.87 & 77.76 \\
$\mathrm{~Pb} \mathrm{10-6}$ & 360 & 293.05 & 27.17 & 0.04 & 0.03 & 96.22 & 18.59 \\
$\mathrm{~Pb} \mathrm{10-8}$ & 360 & 205.19 & 65.35 & 0.07 & 0.05 & 84.37 & 43.00 \\
$\mathrm{~Pb} \mathrm{10-10}$ & 360 & 319.22 & 51.65 & 0.35 & 0.03 & 113.8 & 11.33 \\
\hline
\end{tabular}

\section{Discussion}

In this study, pollutants were removed by applying PRB filled with food waste ash to ground contaminated with copper and lead, using EK remediation techniques. In order to solve the problems of existing EK remediation techniques. PRB, an improver and electrode exchange were applied, and an improved heavy metal removal method was proposed. The conclusions could be obtained through the experimental results of applying the improved EK remediation technique through a cell suitable for indoor experiments.

In the EK remediation technique for copper and lead removal, acetic acid was used to improve the movement of pollutants in the ground to improve remediation efficiency. The amount of outflow water increased both copper and lead due to the injection of samples and enhancers at the point before electrode exchange $(x / L=0 \sim 0.7)$, which is determined to have improved the movement of pollutants due to the smooth inflow of the enhancer. Furthermore, after the end of the experiment, the water content in the sample was maintained at the initial water content of $60 \%$, and it is determined that the movement of the improver was smooth during the EK remediation experiment.

The $\mathrm{pH}$ in the water tank showed a low $\mathrm{pH}$ at the anode due to EK phenomena, and a high $\mathrm{pH}$ at the cathode. It was confirmed that the $\mathrm{pH}$ was lowered rapidly as the existing cathode changed to the anode after the electrode exchange, and the existing anode was stabilized within one day as the initial anode changed to a cathode. This indicates that the movement of hydrogen ions at the anode is more active than that of hydroxide ions at the cathode, which may have improved the movement of heavy metals at $x / L=0.9$ through electrode exchange.

In the case of copper and lead, heavy metal removal was most effective after 10 days of operation and 8 days after electrode exchange. In the case of copper, the removal rate was about $87 \%$, and the remediation efficiency was excellent. In the case of lead, it was confirmed that the remediation efficiency was about $43 \%$ lower than that of copper. A remediation period of 10 days or more was required, and it was determined that a different remediation period according to heavy metals should be applied.

Electrokinetic remediation techniques are economical, can be applied to a variety of ground and pollutants, and can be used in combination with other remediation techniques, so it is expected that they will be applied to contaminated ground.

Author Contributions: Conceptualization, J.-G.H., J.-Y.L. and D.K.; methodology, G.H., D.K., J.-G.H. and J.-Y.L.; validation, D.K., J.-G.H. and J.-M.Y.; formal analysis, D.K., J.-Y.L. and G.H.; investigation, S.L. and J.-S.K.; resources, J.-G.H. and J.-M.Y.; data curation, S.L., J.-S.K. and D.K.; writing-original draft preparation, S.L. and D.K; writing — review and editing, D.K and J.-G.H.; visualization, S.L., J.-S.K. and D.K.; supervision, J.-M.Y., J.-Y.L., G.H. and J.-G.H.; project administration, J.-Y.L., D.K. and J.-G.H. All authors have read and agreed to the published version of the manuscript.

Funding: This research was funded by the Chung-Ang University Excellent Student Scholarship in 2012 and a grant from the National Research Foundation (NRF) of Korea, funded by the Korea government (MSIP) (NRF-2019R1A2C2088962).

Institutional Review Board Statement: Not applicable. 
Informed Consent Statement: Not applicable.

Data Availability Statement: Data presented in this study are available on request from the corresponding author. The data are not publicly available due to data that are also part of an ongoing study.

Acknowledgments: This research was supported by the Chung-Ang University Excellent Student Scholarship in 2012 and a grant from the National Research Foundation (NRF) of Korea, funded by the Korea government (MSIP) (NRF-2019R1A2C2088962).

Conflicts of Interest: The authors declare no conflict of interest.

\section{References}

1. Bo, S.; Luo, J.; An, Q.; Xiao, Z.; Wang, H.; Cai, W.; Zhai, S.; Li, Z. Efficiently selective adsorption of Pb(II) with functionalized alginate-based adsorbent in batch/column systems: Mechanism and application simulation. J. Clean. Prod. 2020, $250,19585$. [CrossRef]

2. Xia, Y.; Tang, Y.; Shih, K.; Li, B. Enhanced phosphorus availability and heavy metal removal by chlorination during sewage sludge pyrolysis. J. Hazard. Mater. 2019, 382, 121110. [CrossRef]

3. Wang, X.; Chen, J.; Yan, X.; Wang, X.; Zhang, J.; Huang, J.; Zhao, J. Heavy metal chemical extraction from industrial and municipal mixed sludge by ultrasound-assisted citric acid. J. Ind. Eng. Chem. 2015, 27, 368-372. [CrossRef]

4. Wu, Q.; Duan, G.; Cui, Y.; Sun, J. Removal of heavy metal species from industrial sludge with the aid of biodegradable iminodisuccinic acid as the chelating ligand. Environ. Sci. Pollut. Res. Int. 2015, 22, 1144-1150. [CrossRef]

5. Wu, Q.; Cui, Y.; Li, Q.; Sun, J. Effective removal of heavy metals from industrial sludge with the aid of a biodegradable chelating ligand GLDA. J. Hazard. Mater. 2015, 283, 748-754. [CrossRef] [PubMed]

6. Hur, J.H.; Jeong, S.W. Effect of Water-Thoroughly-Rinsing in the Artificially Metal-Contaminated Soil Preparation on Final Soil Metal Concentrations. J. Korean Soc. Environ. Eng. 2011, 33, 670-676. [CrossRef]

7. Tang, J.; He, J.; Liu, T.; Xin, X.; Hu, H. Removal of heavy metal from sludge by the combined application of a biodegradable biosurfactant and complexing agent in enhanced electrokinetic treatment. Chemosphere 2017, 189, 599-608. [CrossRef] [PubMed]

8. Ministry of Environment. Soil Measurement Network and Soil Contamination Survey Results in 2005; Ministry of Environment: Sejong-si, Korea, 2005.

9. Liu, H.; Li, J.; Zhao, M.; Li, Y.; Chen, Y. Remediation of oil-based drill cuttings using low-temperature thermal desorption: Performance and kinetics modeling. Chemosphere 2019, 235, 1081-1088. [CrossRef] [PubMed]

10. Liu, T.; Yuan, X.; Zhang, G.; Hu, J.; An, J.; Chen, T.; Wang, G. Stir bar sorptive extraction and automatic two-stage thermal desorption-gas chromatography-mass spectrometry for trace analysis of the byproducts from diphenyl carbonate synthesis. Microchem. J. 2020, 153, 104341. [CrossRef]

11. Zhang, F.; Wang, Y. Remediation of $\mathrm{Cu}, \mathrm{Pb}, \mathrm{Zn}$ and $\mathrm{Cd}$-contaminated agricultural soil using a combined red mud and compost amendment. Int. Biodeterior. Biodegrad. 2017, 118, 73-81.

12. Wang, F.; Shen, Z.; Liu, R.; Zhang, Y.; Xu, J.; Al-Tabbaa, A. GMCs stabilized/solidified Pb/Zn contaminated soil under different curing temperature: Physical and microstructural properties. Chemosphere 2020, 239, 124738. [CrossRef]

13. Muddanna, M.H.; Baral, S.S. A comparative study of the extraction of metals from the spent fluid catalytic cracking catalyst using chemical leaching and bioleaching by Aspergillus niger. J. Environ. Chem. Eng. 2019, 7, 103335. [CrossRef]

14. Cameselle, C. Enhancement of electro-osmotic flow during the electrokinetic treatment of A contaminated soil. Electrochim. Acta 2015, 181, 31-38. [CrossRef]

15. Liu, Y.; Zhu, H.; Zhang, M.; Chen, R.; Chen, X.; Zheng, X.; Jin, Y. Cr(VI) recovery from chromite ore processing residual using an enhanced electrokinetic process by bipolar membranes. J. Membr. Sci. 2018, 566, 190-196. [CrossRef]

16. Fu, R.; Wen, D.; Xia, X.; Zhang, W.; Gu, Y. Electrokinetic remediation of chromium (Cr)-contaminated soil with citric acid (CA) and polyaspartic acid (PASP) as electrolytes. Chem. Eng. J. 2017, 316, 601-608. [CrossRef]

17. Tang, J.; He, J.; Xin, X.; Hu, H.; Liu, T. Biosurfactants enhanced heavy metals removal from sludge in the electrokinetic treatment. Chem. Eng. J. 2018, 334, 2579-2592. [CrossRef]

18. Falciglia, P.P.; Malarbì, D.; Vagliasindi, F.G.A. Removal of mercury from marine sediments by the combined application of a biodegradable non-ionic surfactant and complexing agent in enhanced-electrokinetic treatment. Electrochim. Acta 2016, 222, 1569-1577. [CrossRef]

19. Falciglia, P.P.; Malarbì, D.; Maddalena, R.; Greco, V.; Vagliasindi, F.G.A. Remediation of Hg-contaminated marine sediments by simultaneous application of enhancing agents and microwave heating (MWH). Chem. Eng. J. 2017, 321, 1-10. [CrossRef]

20. Falciglia, P.P.; Malarbì, D.; Greco, V.; Vagliasindi, F.G.A. Surfactant and MGDA enhanced-Electrokinetic treatment for the simultaneous removal of mercury and PAHs from marine sediments. Sep. Purif. Technol. 2017, 175, 330-339. [CrossRef]

21. Qiu, M.; He, C. Efficient removal of heavy metal ions by forward osmosis membrane with a polydopamine modified zeolitic imidazolate framework incorporated selective layer. J. Hazard. Mater. 2019, 367, 339-347. [CrossRef] [PubMed]

22. Mendez, E.; Perez, M.; Romero, O.; Beltran, E.D.; Castro, S. Effects of electrode material on the efficiency of hydrocarbon removal by an electrokinetic remediation process. Electrochim. Acta 2012, 86, 148-156. [CrossRef] 
23. Suzuki, T.; Kawai, K.; Moribe, M.; Niinae, M. Recovery of $\mathrm{Cr}$ as $\mathrm{Cr}(\mathrm{III})$ from $\mathrm{Cr}(\mathrm{VI})$-contaminated kaolinite clay by electrokinetics coupled with a permeable reactive barrier. J. Hazard Mater. 2014, 278, 297-303. [CrossRef]

24. Yuan, L.; Li, H.; Xu, X.; Zhang, J.; Wang, N.; Yu, H. Electrokinetic remediation of heavy metals contaminated kaolin by a CNT-covered polyethylene terephthalateyarn cathode. Electrochim. Acta 2016, 213, 140-147. [CrossRef]

25. Wang, L.; Huang, L.; Xia, H.; Li, H.; Li, X.; Liu, X. Application of a multielectrode system with polyaniline auxiliary electrodes for electrokinetic remediation of chromium-contaminated soil. Separ. Purif. Technol. 2019, 224, 106-112. [CrossRef]

26. Alshawabkeh, A.N.; Gale, R.J.; Ozsu-Acar, E.; Bricka, R.M. Optimization of 2-D electrode configuration for electrokinetic remediation. J. Soil Contam. 2010, 8, 617-635. [CrossRef]

27. Turer, D.; Genc, A. Assessing effect of electrode configuration on the efficiency of electrokinetic remediation by sequential extraction analysis. J. Hazard Mater. 2005, 119, 167-174. [CrossRef]

28. Zhou, D.; Deng, C.; Cang, L.; Alshawabkeh, A.N. Electrokinetic remediation of a CueZn contaminated red soil by controlling the voltage and conditioning catholyte $\mathrm{pH}$. Chemosphere 2005, 61, 519-527. [CrossRef]

29. Baek, K.; Kim, D.H.; Park, S.W.; Ryu, B.G.; Bajargal, T. Electrolyte conditioning enhanced electrokinetic remediation of arseniccontaminated mine tailing. J. Hazard Mater. 2009, 161, 457-462. [CrossRef] [PubMed]

30. Juan, A.O.; Peng, C.S.; Abou-Shady, A. Simultaneous removal of cadmium from kaolin and catholyte during soil electrokinetic remediation. Desalination 2012, 300, 1-11.

31. Ryu, B.G.; Park, G.; Yang, J.; Baek, K. Electrolyte conditioning for electrokinetic remediation of As, Cu, and Pb-contaminated soil. Separ. Purif. Technol. 2011, 79, 170-176. [CrossRef]

32. Jelusic, M.; Vodnik, D.; Lestan, D. Revitalization of EDTA-remediated soil by fertilization and soil amendments. Ecol. Eng. 2014, 73, 429-438. [CrossRef]

33. Jez, E.; Lestan, D. EDTA retention and emissions from remediated soil. Chemosphere 2016, 151, 202-209. [CrossRef] [PubMed]

34. Giannis, A.; Nikolaou, A.; Pentari, D.; Gidarakos, E. Chelating agent-assisted electrokinetic removal of cadmium, lead and copper from contaminated soils. Environ. Pollut. 2009, 157, 3379-3386. [CrossRef]

35. Cappai, G.; Gioannis, G.D.; Muntoni, A.; Spiga, D.; Zijlstra, J. Combined use of a transformed red mud reactive barrier and electrokinetics for remediation of $\mathrm{Cr} /$ As contaminated soil. Chemosphere 2012, 86, 400-408. [CrossRef]

36. Obiri-Nyarko, F.; Grajales-Mesa, S.J.; Malina, G. An overview of permeable reactive barriers for in situ sustainable groundwater remediation. Chemosphere 2014, 111, 243-259. [CrossRef]

37. Ramadan, B.S.; Sari, G.L.; Rosmalina, R.T.; Effendi, A.J. An overview of electrokinetic soil flushing and its effect on bioremediation of hydrocarbon contaminated soil. J. Environ. Manag. 2018, 218, 309-321. [CrossRef]

38. Wang, G.; Zhang, S.; Zhong, Q.; Xu, X.; Li, T.; Jia, Y.; Zhang, Y.; Peijnenburg, W.J.G.M.; Vijver, M.G. Effect of soil washing with biodegradable chelators on the toxicity of residual metals and soil biological properties. Sci. Total Environ. 2018, 625, 1021-1029. [CrossRef]

39. Liu, L.; Li, W.; Song, W.; Guo, M. Remediation techniques for heavy metal contaminated soils: Principles and applicability. Sci. Total Environ. 2018, 633, 206-219. [CrossRef] [PubMed]

40. Hu, W.; Feng, S.; Tong, Y.; Zhang, H.; Yang, H. Adaptive defensive mechanism of bioleaching microorganisms under extremely environmental acid stress: Advances and perspectives. Biotechnol. Adv. 2020, 42, 107580. [CrossRef] [PubMed]

41. Luo, J.; Wu, J.; Huo, S.; Qi, S.; Gu, X.S. A real scale phytoremediation of multimetal contaminated e-waste recycling site with Eucalyptus globulus assisted by electrical fields. Chemosphere 2018, 201, 262-268. [CrossRef]

42. Ali, H.; Khan, E.; Sajad, M.A. Phytoremediation of heavy metalsdconcepts and applications. Chemosphere 2013, 91, 869-881. [CrossRef]

43. Mao, X.; Han, F.X.; Shao, X.; Guo, K.; McComb, J.; Arslan, Z.; Zhang, Z. Electro-kinetic remediation coupled with phytoremediation to remove lead, arsenic and cesium from contaminated paddy soil. Ecotoxicol. Environ. Saf. 2016, 125, 16-24. [CrossRef] [PubMed]

44. Reddy, K.R. Electrokinetic remediation of soils at complex contaminated sites: Technology status, challenges, and opportunities. In Coupled Phenomena in Environmental Geotechnics; CRC Press: Boca Raton, FL, USA, 2013; pp. 131-147.

45. Dalloway, B.J. Heavy Metals in Soils; John Wiley \& Sons Inc.: New York, NY, USA, 1990; p. 339.

46. Lockhart, N.C. Electro-osmotic dewatering of clay-III. Influence of clay type, exchangeable cations and electrode materials. Colloids Surf. 1983, 6, 253-269. [CrossRef]

47. McMutry, D.C.; Elton, R.O. New approach to in-situ treatment of contaminated groundwaters. Environ. Prog. 1985, 4, 168-170. [CrossRef]

48. Narasimhan, B.; Ranjan, R.S. Electrokinetic barrier to prevent subsurface contaminant migration: Theoretical model development and validation. J. Contam. Hydrol. 2000, 42, 1-17. [CrossRef]

49. Zhu, N.M.; Qiang, L.; Guo, X.J.; Hui, Z.; Yu, D. Sequential extraction of anaerobic digestate sludge for the determination of partitioning of heavy metals. Ecotoxicol. Environ. Saf. 2014, 102, 18-24. [CrossRef]

50. Zhu, N.-M.; Chen, M.; Guo, X.-J.; Hu, G.-Q.; Yu, D. Electrokinetic removal of Cu and Zn in anaerobic digestate: Interrelation between metal speciation and electrokinetic treatments. J. Hazard. Mater. 2015, 286, 118-126. [CrossRef]

51. Zhu, S.; Zhu, D.; Wang, X. Removal of fluorine from red mud (bauxite residue) by electrokinetics. Electrochim. Acta 2017, 242, 300-306. [CrossRef]

52. Wang, S.; Mulligan, C.N. Rhamnolipid biosurfactant-enhanced soil flushing for the removal of arsenic and heavy metals from mine tailings. Process Biochem. 2009, 44, 296-301. [CrossRef] 
53. Yong, R.N.; Mohamed, A.M.O.; Warkentin, B.P. Principles of Contaminant Transport in Soils; Elsevier Science: Amsterdam, The Netherlands, 1992.

54. Zhang, P.; Jin, C.; Sun, Z.; Huang, G.; She, Z. Assessment of acid enhancement schemes for electrokinetic remediation of Cd/Pb contaminated soil. Water Air Soil Pollut. 2016, 227, 1-12. [CrossRef]

55. Yang, J.S.; Man, J.K.; Choi, J.; Baek, K.; O’Loughlin, E.J. The transport behavior of As, Cu, Pb, and Zn during electrokinetic remediation of a contaminated soil using electrolyte conditioning. Chemosphere 2014, 117, 79-86. [CrossRef] [PubMed]

56. Annamalai, S.; Santhanam, M.; Sundaram, M.; Curras, M.P. Electrokinetic remediation of inorganic and organic pollutants in textile effluent contaminated agricultural soil. Chemosphere 2014, 117, 673-678. [CrossRef] [PubMed]

57. Wen, D.D.; Fu, R.B.; Zhang, W.; Gu, Y.Y. Enhanced electrokinetic remediation of heavy metals contaminated soils by stainless steel electrodes as well as the phenomenon and mechanism of electrode corrosion and crystallization. Huanjing Kexue 2017, 38, 1209-1217. [PubMed]

58. Wang, J.; Huang, X.; Kao, J.; Stabnikova, O. Removal of heavy metals from kaolin using an upward electrokinetic soil remedial (UESR) technology. J. Hazard Mater. 2006, 136, 532-541. [CrossRef] 